\title{
Assessment of antibiotics production potentials in four actinomycetes isolated from aquatic environments of the Eastern Cape Province of South Africa
}

\author{
Cwala Z., Igbinosa E. O. and Okoh A. I.* \\ Applied and Environmental Microbiology Research Group (AEMREG), Department of Biochemistry and Microbiology, \\ University of Fort Hare, Alice 5700, Private Bag X1314, South Africa.
}

Accepted 21 January, 2011

\begin{abstract}
Crude extracts of four actinomycetes species belonging to Actinoplane [NB 034], Streptomyces [TR 007] and Actinopolyspora [NB 069 and TR 008] genera were screened for antibacterial activities against a wide range of bacterial strains. The extracts showed antibacterial activities against both Gram-negative and Gram-positive test bacteria with zones of inhibition ranging between 2 and $27 \mathrm{~mm}$ (NB 034); 9 and $15 \mathrm{~mm}$ (TR 007); 8 and13 (NB 069) and 2 and $12 \mathrm{~mm}$ (NB 069). The minimum inhibitory concentration (MIC) of the extracts against the test bacteria ranged from $0.039-5 \mathrm{mg} / \mathrm{ml}$, while the minimum bactericidal concentrations (MBC) ranged from 5 to $>10 \mathrm{mg} / \mathrm{ml}$. The extracts exhibited concentrationtime dependent killing of Staphylococcus aureus OKOH2A and Staphylococcus scuiri OKOH2B with a $0.73 \log _{10}$ and $0.88 \log _{10}$ reduction in viable counts respectively, while a re-growth phenomenon was exhibited by Klebsiella pneumonia ATCC 4352 and Escherichia coli ATCC 25922 at MIC, $2 \times$ MIC and $4 \times$ MIC of Streptomyces (TR 007) Actinopolyspora (TR 008) extracts. All the active extracts exhibited bacteriostatic activities.
\end{abstract}

Key words: Actinoplane, streptomyces, actinopolyspora, antibiotic production.

\section{INTRODUCTION}

The actinomycetes are Gram positive bacteria having high $\mathrm{G}+\mathrm{C}(>55 \%)$ content in their DNA. They were originally considered to be an intermediate group between bacteria and fungi but now are recognized as prokaryotic organisms which are widely distributed in soil, water and found colonizing plants (Jensen and Fenical, 2000; Ogunmwonyi, 2008). The actinomycetes are noteworthy as antibiotic producers, making three quarters of all known products and other class of biologically active secondary metabolites (Okami and Hotta 1988). In the past two decades, however, there has been a decline in

\footnotetext{
${ }^{\star}$ Corresponding author. E-mail: aokoh@ufh.ac.za.
}

Abbreviations: MIC, represents minimum inhibitory concentration; MBC, minimum bactericidal concentration; LPS, lipopolysaccharides. the discovery of new important compounds from common soil-derived actinomycetes as culture extracts yield unacceptably high numbers of previously described metabolites (Mincer et al., 2002). Hence, the need for increased exploration of previously unexplored habitats for new actinomycete taxa has become a major focus in the search for the next generation of pharmaceutical agents (Bull et al., 2000), especially with the increasing trend in development of antibiotic resistance in microbial pathogens.

Actinomycetes from the genera Actinoplane, Streptomyces, and Actinopolyspora have been reported to produce over 300 broad-spectrum antibiotic substances (Kieser et al., 2000; Wynands and van Pee, 2004) and representatives of these genera are widely abundant in aquatic ecosystems.

Each year thousands of Streptomyces strains are screened by pharmaceutical companies as source of new antimicrobial compounds (Zhang et al., 2002). The first 
antibiotic that was discovered from this genus was Streptothricin which was discovered in 1942. However, it was streptomycin in 1944 that triggered screening of antibiotics from Streptomyces and since 1942 a lot of screening efforts for more antibiotics have been made in this genus (Berdy, 1974; Vandamme, 1984). However, discovery of new Streptomyces strains has substantially decreased over the years, and so has the probability of discovering a new compound (Watve et al., 2001). Some Actinoplanes species produce enzymes and metabolites of medical relevance. Typical example is Actinoplanes missouriensis which produces xylose isomerase (Karimaki et al., 2004).

Actinopolyspora is said to have an elongated and circular shape with 20-30 spore-chain structures (XiaoYang et al., 2000). Not much research has been done concerning Actinopolyspora as a source of antibiotic producing organism.

In this paper, we report on the antibacterial potentials of antibiotic compounds produced by three actinomycetes isolates belonging to the genera Actinoplane, Actinopolyspora and Streptomyces and isolated from the aquatic environment of the Eastern Cape Province of South Africa as part of our ongoing search of new antimicrobial compounds.

\section{MATERIALS AND METHODS}

\section{Test actinomycetes}

Four actinomycetes strains tentatively identified as belonging to the genera Actinoplane [NB 034], Streptomyces (TR 007) and Actinopolyspora (NB 069 and TR 008) were obtained from the culture collection of the Applied and Environmental Microbiology Research Group (AEMREG), University of Fort Hare, Alice, South Africa. The strains were isolated from the Nahoon beach and Tyume River (Ogunmwonyi, 2008) in the Eastern Cape Province of South Africa. The organisms were maintained on agar slants and in $20 \%$ glycerol at $-80^{\circ} \mathrm{C}$. The test actinomycetes suspensions were prepared by suspending a loopful of pure actinomycetes colony in $10 \mathrm{ml}$ sterile physiological saline, vortexed to homogenize and stored at $4^{\circ} \mathrm{C}$ until ready for use. This suspension was used as actinomycetes inoculants in all cultivations.

\section{Test bacteria}

The test bacteria used in this study were obtained from AEMREG culture collection Bank University of Fort Hare, Alice, South Africa, and include the following:

\section{Referenced strains}

Escherichia coli ATCC 25922; Pseudomonas aeruginosa ATCC 19582; Staphylococcus aureus ATCC 6538; Streptococcus faecalis ATCC 29212; Bacillus cereus ATCC 10702; Bacillus pumilus ATCC 14884; Pseudomonas aeruginosa ATCC 7700; Enterobacter cloacae ATCC 13047; Klebsiella pneumoniae ATCC 10031; Klebsiella pneumoniae ATCC 4352; Proteus vulgaris ATCC 6830; Proteus vulgaris CSIR 0030; Serratia marcescens ATCC 9986; Acinetobacter calcoaceticus UP; and Acinetobacter calcoaceticus anitratus CSIR.

\section{Environmental strains}

Klebsiella pneumoniae, Bacillus subtilis, Shigella dysenteriae, Staphylococcus epidermidis, Pseudomonas aeruginosa, Proteus vulgaris, Enterococcus faecalis, Staphylococcus aureus, Micrococcus kristinae and Micrococcus luteus.

\section{Clinical isolates}

Staphylococcus aureus OKOH1, Staphylococcus aureus OKOH2A, Staphylococcus aureus $\mathrm{OKOH}$, and Staphylococcus aureus $\mathrm{OKOH} 2 \mathrm{~B}$ with Gene Bank accession numbers Eu244633, Eu244634, Eu244635 and Eu244636 respectively.

\section{Preparation of test bacteria}

The test bacteria were grown in nutrient broth and incubated at $37^{\circ} \mathrm{C}$ for $24 \mathrm{~h}$. The cells were centrifuged at $7000 \mathrm{rpm}$, washed with sterile physiological saline and standardized to $\mathrm{OD}_{600 \mathrm{~nm}} 0.1$ and stored at $4^{\circ} \mathrm{C}$ until ready for use.

\section{Preparation and inoculation of fermentation medium}

The fermentation broth was prepared as follows per litre: $10 \mathrm{~g}$ starch, $4 \mathrm{~g}$ yeast extract, $2 \mathrm{~g}$ peptone, $5 \mathrm{ml}$ potassium bromide (20 $\mathrm{g} / \mathrm{L}$ ) and $5 \mathrm{ml}$ Iron (III) sulphate tetrahydrate (4.76 g/L). The medium was aliquoted in $500 \mathrm{ml}$ Erlenmeyer flasks and sterilized by autoclaving at $121^{\circ} \mathrm{C}$ and $15 \mathrm{mmHg}$ for $15 \mathrm{~min}$ and allowed to cool after which $100 \mu \mathrm{l}$ of the standardized actinomycetes suspension were used to inoculate the flasks and incubated at $27^{\circ} \mathrm{C}$ on a shaker at $300 \mathrm{rpm}$ for 10 days.

\section{Extraction of crude antibiotic metabolites from fermentation cultures}

The crude extracts of the fermentation products were recovered from the culture filtrate by solvent extraction using ethyl acetate in accordance with the description of Thakur et al. (2007). Ethyl acetate was added to the filtrate in the ratio $1: 1(\mathrm{v} / \mathrm{v})$ and shaken vigorously for complete extraction.

The ethyl acetate phase that contains the crude antibiotic metabolites was separated from the aqueous phase and concentrated in vacuo at $60^{\circ} \mathrm{C}$ using a rotary evaporator. The residue obtained was weighed and reconstituted in $50 \%$ methanol for the antibacterial assays.

\section{Antibacterial susceptibility test}

The antibacterial activities of the crude ethyl acetate extracts were determined using agar well diffusion method as described by Pandey et al. (2004). Twenty milliliters of sterilized molten Mueller Hinton agar (MHA) was seeded with $50 \mu \mathrm{l}$ of standardized test bacteria, swirled gently and aseptically poured into Petri dishes and allowed to solidify.

Sterile cork borer (6 $\mathrm{mm}$ diameter) was used to bore wells in the plate, and $100 \mu \mathrm{l}$ of the crude ethyl acetate extract at a concentration of $10 \mathrm{mg} / \mathrm{ml}$ was then carefully dispensed into the bored holes. The extract was allowed to diffuse for about $1 \mathrm{~h}$ before incubating aerobically at $37^{\circ} \mathrm{C}$ for $24 \mathrm{~h}$. The presence of a zone of inhibition around each well was indicative of antibacterial activity. Control experiments were carried out by loading $100 \mu \mathrm{l}$ of $50 \%$ methanol in place of the extracts. 
Determination of the minimum inhibitory concentration (MIC) and minimum bactericidal concentration (MBC)

The MICs were determined using test organisms that showed susceptibility to the crude extracts by the broth microdilution method as outlined by the EUCAST discussion Document (2003) and as described in our previous report (Sibanda et al., 2010). Briefly, sterile plastic, disposable microtitre plates with 96 flat-bottom wells were used. The medium used in the plates was prepared at double the final strength to allow for a $50 \%$ dilution once the inoculum and solvents/ or antimicrobial were added. A $100 \mu \mathrm{l}$ volume of double strength Muller Hinton broth was introduced into all the 96 wells and varying concentrations of the antibiotic were added in decreasing order along the wells after which wells were loaded with $50 \mu$ of the test organism suspension. The plates were then incubated at $37^{\circ} \mathrm{C}$ for 18-24 h. Wells in column 12 were used as the growth controls and contained $50 \mu \mathrm{l}$ of test organism and $50 \mu \mathrm{l}$ of sterile distilled water.

Results were read using a microtitre plate reader (BIO-RAD model 680 ) at $490 \mathrm{~nm}$. Visual reading of results was also done by first adding resazurin dye into all the wells. Wells with no growth turned blue in colour while those with growth turned pink, and this helped to give a clear visual demarcation of the MIC wells. The minimum inhibitory concentration (MIC) was estimated as the lowest concentration of the extract that inhibited growth of the test organisms.

The minimum bactericidal concentration $(\mathrm{MBC})$ was determined from the MIC plate following a method outlined by the CLSI (2005), and is defined as the lowest concentration of an antibiotic that under defined in vitro conditions reduces by $99.9 \%$ the number of organisms in a medium containing a defined inoculum of bacteria, within a defined period of time (EUCAST Definitive Document, 2000). It was determined by inoculating the broths in the MIC range into drug-free nutrient agar medium. The MBC was determined as the antibiotic concentration at which no growth was observed after incubation for $48 \mathrm{~h}$.

\section{Determination of the time kill assay}

The time-kill assay of the crude extracts were done in accordance with the description of Okoli and Iroegbu (2005) by determining the rate of bacterial cell-death with respect to time using highly susceptible and minimally susceptible Gram positive and Gram negative test bacteria. The inoculum was prepared following the described guidelines of EUCAST (2003). The resultant cell suspension was diluted 1:100 with fresh sterile nutrient broth and used to inoculate $50 \mathrm{ml}$ volume of Mueller Hinton broth incorporated with extract at multiples of the MIC to a final cell density of $5 \times 10^{5}$ $\mathrm{cfu} / \mathrm{ml}$ (Sibanda and Okoh, 2008).

The flasks were incubated with shaking at $37^{\circ} \mathrm{C}$ in an orbital shaker at $120 \mathrm{rpm}$ (Sibanda and Okoh, 2008; Sibanda et al., 2010). Samples of $100 \mu \mathrm{l}$ were withdrawn at $6 \mathrm{~h}$ intervals and diluted appropriately and known volumes of the diluted samples were plated out in triplicate on Mueller Hinton agar. Plates were incubated for $37^{\circ} \mathrm{C}$ for $24 \mathrm{~h}$ after which the numbers of surviving cells were enumerated (Sibanda and Okoh, 2008; Sibanda et al., 2010). Controls consisted of extract free Mueller Hinton broth inoculated with test bacteria.

\section{Statistical analysis}

Results were analyzed using a student t-test and One-way analysis of variance (ANOVA). Mean zone diameters were compared for all the four actinomycetes extracts. Analysis was carried out at $P<$ 0.05 .

\section{RESULTS}

\section{Antibacterial activities of the crude extracts}

The results of the antibacterial activities of the crude extracts of the fermentation products are shown in Table 1. A total of 4 actinomycetes extracts were screened against 29 test bacteria. Actinopolyspora [NB069] extract showed antibacterial activities against four of the test bacteria with zones of inhibition ranging between 8-13 $\mathrm{mm}$, while Actinopolyspora (TR 008) extract was active against five test bacteria with zones of inhibition varying between 2 and12 mm. Actinoplane [NB 034] and Streptomyces (TR 007) extracts were active against 7 and 15 test bacteria with inhibition zones ranging from 2 to $27 \mathrm{~mm}$, and 9 to $15 \mathrm{~mm}$ respectively. None of the extracts were active against Proteus vulgaris CSIR 0030, Streptococcus faecalis ATCC 29212, Enterobacter cloacae ATCC 13047, and Shigella dysenteriae (Environmental strains). It appear that Actinoplane (NB 034) produced more potent antibacterial compound as it exhibited larger inhibition zone than all other extracts, although it showed no activity against all clinical isolates.

\section{MIC and MBC assay}

The minimum inhibitory concentrations (MIC) of the four extracts are presented in Table 2. The MICs of the extract Streptomyces (TR 007) ranged from 0.15 to 5 $\mathrm{mg} / \mathrm{ml}$, while the MBC ranged from 5 to $>10 \mathrm{mg} / \mathrm{ml}$. For extract of Actinopolyspora (TR 008), MIC varied between 0.039 and $5 \mathrm{mg} / \mathrm{ml}$ while $\mathrm{MBC}$ ranged from 2.5 to $>10$ $\mathrm{mg} / \mathrm{ml}$. The MICs for Actinopolyspora (NB 069) and Actinoplane (NB 034) were $5 \mathrm{mg} / \mathrm{ml}$ and 2.5 to $5 \mathrm{mg} / \mathrm{ml}$ respectively, while their MBCs ranged between 5 and $>10$ $\mathrm{mg} / \mathrm{ml}$ and generally $>10 \mathrm{mg} / \mathrm{ml}$ respectively. It appears that the extracts are more active against Gram negative bacteria than Gram positive ones.

\section{Time kill assay}

The time kill studies were conducted for antibiotic metabolites from Streptomyces [TR 007] and Actinopolyspora (TR 008). Table 3 shows the $\log _{10}$ change in viable counts of selected test bacteria following exposure to varying concentrations of the extracts. The rate of kill of the test bacterial cells varied with concentration of extract and duration of exposure. The viable cell count of Streptomyces (TR 007) extract against Staphylococcus aureus (OKOH2A) was observed to range from 0.22 to 0.73 . Also, the viable cell count of Streptomyces (TR 007) extract against Staphylococcus sciuri $(\mathrm{OKOH} 2 \mathrm{~B})$ ranged between 0.51 and 0.88 . Regrowth in Escherichia coli counts was observed at all concentrations of Streptomyces (TR 007) extract tested at all exposure times. A similar trend was observed for 
Table 1. Antibacterial activities of crude extracts of fermentation products of the four test actinomycetes.

\begin{tabular}{|c|c|c|c|c|}
\hline \multirow{2}{*}{ Test organisms } & \multicolumn{4}{|c|}{ Antibacterial activity [inhibition zones, $(\mathrm{mm})]$} \\
\hline & NB 034 & NB069 & TR 007 & TR008 \\
\hline Escherichia coli ATCC 25922@ & - & - & $+(11)$ & - \\
\hline Pseudomonas aeruginosa ATCC $7700^{@}$ & - & - & - & - \\
\hline Staphylococcus aureus ATCC 6535 ${ }^{@}$ & - & - & - & $+(5)$ \\
\hline Streptococcus faecalis ATCC $29212^{@}$ & - & - & - & - \\
\hline Bacillus cereus ATCC 10702@ & - & - & - & - \\
\hline Bacillus pumilus ATCC 10702@ & - & - & $+(15)$ & - \\
\hline Pseudomonas aeruginosa ATCC $19582^{@}$ & - & - & - & $+(12)$ \\
\hline Enterobacter cloacae ATCC 13047@ & - & - & - & - \\
\hline Klebsiella pneumoniae ATCC 10031@ & - & - & $+(12)$ & - \\
\hline Klebsiella pneumoniae ATCC 4352@ & - & - & $+(14)$ & $+(2)$ \\
\hline Proteus vulgaris ATCC 6830@ & - & - & - & - \\
\hline Proteus vulgaris CSIR 0030@ & $+(27)$ & - & - & - \\
\hline Serratia marcescens ATCC $9986^{@}$ & $+(22)$ & $+(12)$ & - & - \\
\hline Acinetobacter calcoaceticus UP@ & $+(12)$ & - & - & - \\
\hline Acinetobacter calcoaceticus anitratus CSIR @ & - & - & $+(10)$ & - \\
\hline$K_{\text {Klebsiella pneumoniae }}{ }^{\circledR}$ & $+(15)$ & - & - & - \\
\hline Bacillus subtilis ${ }^{\circledR}$ & - & - & $+(13)$ & - \\
\hline Shigella dysenteriae ${ }^{\circledR}$ & - & - & - & - \\
\hline Staphylococcus epidermidis ${ }^{\circledR}$ & $+(5)$ & - & $+(13)$ & - \\
\hline Pseudomonas aeruginosa ${ }^{\circledR}$ & $+(17)$ & $+(11)$ & - & - \\
\hline Proteus vulgaris $^{\circledR}$ & - & - & - & - \\
\hline Enterococcus faecalis ${ }^{\circledR}$ & $+(2)$ & $+(8)$ & $+(15)$ & - \\
\hline Staphylococcus aureus ${ }^{\circledR}$ & - & - & $+(9)$ & - \\
\hline Micrococcus kristinae ${ }^{\circledR}$ & - & - & $+(12)$ & - \\
\hline Micrococcus luteus $^{\circledR}$ & - & - & $+(11)$ & $+(2)$ \\
\hline Staphylococcus aureus $\mathrm{OKOH} 1^{T M}$ & - & $+(13)$ & $+(9)$ & $+(5)$ \\
\hline Staphylococcus aureus $\mathrm{OKOH} 2 \mathrm{~A}^{\mathrm{TM}}$ & - & - & $+(12)$ & - \\
\hline Staphylococcus sciuri $\mathrm{OKOH} 2 \mathrm{~B}^{T M}$ & - & - & $+(13)$ & - \\
\hline Staphylococcus aureus $\mathrm{OKOH} 3^{\text {TM }}$ & - & - & $+(11)$ & - \\
\hline
\end{tabular}

${ }^{\mathrm{TM}}$ Clinical isolates, ${ }^{\circledR}$ Environmental strains, ${ }^{\circledR}$ References strains, - no activity, + activity. Actinoplane [NB 034], Streptomyces [TR 007], and Actinopolyspora [NB 069 and TR 008]

Klebsiella pneumoniae (ATCC 4352) but only after $12 \mathrm{~h}$ of exposure to the Streptomyces (TR 007) and at the three concentrations tested Table 3. On the other hand, with the Actinopolyspora (TR 008) antibiotic metabolites only Micrococcus luteus was observed to reduce in cell counts within $6 \mathrm{~h}$ of exposure, but in $12 \mathrm{~h}$ the test bacteria increased in growth beyond the initial cell density at all test concentrations as observed in all concentrations and exposure times for Klebsiella pneumoniae Table 4.

\section{DISCUSSION}

Streptomyces are Gram positive filamentous bacteria which belong to the order Actinomycetales (Madigan and Martinko, 2005). The natural habitat of most Streptomyces is the soil but can be also found in aquatic environment. The most intriguing trait of Streptomyces is the capacity to produce secondary metabolites including antibiotics and bioactive compounds valued in human and veterinary medicine, agriculture, and unique biochemical tools (Omura, 2001), and the now uncommonly-used streptomycin takes its name directly from Streptomyces (Kampfer, 2006).

Actinoplane is a genus which belongs to the family Actinoplanaceae. Actinoplanes species are active antibiotic producers. For example, the ramoplanin complex, teicoplanin, friulimicin, purpuromycin and pentachloropseudilin (Wynands and van Pee, 2004) are produced by Actinoplanes species. Actinoplanes garbadinensis nov. spp produces a peptide antibiotic which is active in vitro and in vivo against Gram-positive bacteria, inhibiting their growth by interfering with cell-wall synthesis (Coronelli et al., 1976).

Actinopolyspora is a group of highly halophilic 
Table 2. Minimum inhibitory concentration and minimum bactericidal concentration of crude extracts of fermentation products of the four test actinomycetes.

\begin{tabular}{|c|c|c|c|c|}
\hline Extract code & Test organisms & Gram reaction & MIC (mg/ml) & $\mathrm{MBC}(\mathrm{mg} / \mathrm{ml})$ \\
\hline \multicolumn{5}{|l|}{ TR 007} \\
\hline & Micrococcus Kristinae ${ }^{\circledR}$ & + & 5 & 5 \\
\hline & Bacillus subtilis ATCC 10702@ & + & 2.5 & 5 \\
\hline & Staphylococcus aureus $\mathrm{OKOH} 2 \mathrm{~A}^{\mathrm{TM}}$ & + & 1.25 & 10 \\
\hline & Staphylococcus aureus $\mathrm{OKOH} 3^{T M}$ & + & 1.25 & $>10$ \\
\hline & Staphylococcus sciuri $\mathrm{OKOH} 2 \mathrm{~B}^{\mathrm{TM}}$ & + & 0.625 & $>10$ \\
\hline & Acinetobacter calcaoceticus anitratus CSIR & - & 0.625 & $>10$ \\
\hline & Micrococcus luteus ${ }^{\circledR}$ & + & 2.5 & $>10$ \\
\hline & Staphylococcus epidermidis ${ }^{\circledR}$ & + & 5 & 5 \\
\hline & Enterococcus faecalis ${ }^{\circledR}$ & + & 2.5 & $>10$ \\
\hline & Staphylococcus aureus ATCC $6538^{@}$ & + & 2.5 & 10 \\
\hline & Staphylococcus aureus $\mathrm{OKOH} 1^{T M}$ & + & 5 & $>10$ \\
\hline & Escherichia coli ATCC 25922@ & - & 0.315 & $>10$ \\
\hline & Bacillus pumilus ATCC 14884@ & + & 0.625 & $>10$ \\
\hline & Klebsiella pneumoniae ATCC $4352^{@}$ & - & 0.156 & $>10$ \\
\hline & Klebsiella pneumoniae ${ }^{\circledast}$ & - & 0.315 & $>10$ \\
\hline \multicolumn{5}{|l|}{ TR 008} \\
\hline & Micrococcus luteus ${ }^{\circledR}$ & + & 0.039 & $>10$ \\
\hline & Klebsiella pneumoniae ${ }^{\circledR}$ & - & 0.039 & $>10$ \\
\hline & Staphylococcus aureus ATCC $6538^{\circledR}$ & + & 5 & 5 \\
\hline & Staphylococcus aureus $\mathrm{OKOH} 2 \mathrm{~A}^{T M}$ & - & 2.5 & 2.5 \\
\hline \multicolumn{5}{|l|}{ NB 069} \\
\hline & Serratia marcescens ATCC 9986@ & - & 5 & 5 \\
\hline & Pseudomonas aeruginosa ATCC $19582^{@}$ & - & 5 & 10 \\
\hline & Enterococcus faecalis $^{\circledR}$ & + & 5 & $>10$ \\
\hline & Staphylococcus aureus $\mathrm{OKOH} 1^{\text {TM }}$ & + & 5 & 10 \\
\hline \multicolumn{5}{|c|}{ 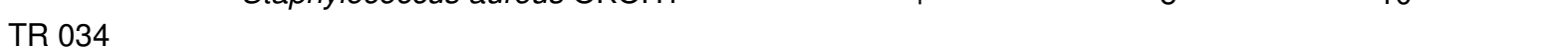 } \\
\hline & Proteus vulgaris CSIR 0030@ & - & 5 & $>10$ \\
\hline & Serratia marcescens ATCC 9986@ & - & 2.5 & $>10$ \\
\hline & Acinetobacter calcaoceticus UP @ & - & 2.5 & $>10$ \\
\hline & Klebsiella pneumoniae ATCC 10031@ & - & 5 & $>10$ \\
\hline & Staphylococcus epidermidis ${ }^{\circledR}$ & + & 5 & $>10$ \\
\hline & Enterococcus faecalis ${ }^{\circledR}$ & + & 5 & $>10$ \\
\hline & Pseudomonas aeruginosa ${ }^{\circledR}$ & - & 5 & $>10$ \\
\hline
\end{tabular}

${ }^{\circledR}$ Environmental strains; ${ }^{\top \mathrm{M}} \mathrm{Clinical}$ isolates; ${ }^{@}$ Reference strains; - represents not Susceptible activity; + represent Susceptible; MICMinimum inhibitory concentration; MBC- Minimum bactericidal concentration.

Actinoplane [NB 034], Streptomyces [TR 007], and Actinopolyspora [NB 069 and TR 008]

filamentous actinomycetes. Members of this group are isolated frequently in hypersaline soil environment. Since 1975 , only two species of extremely halophilic actinomycetes have been reported, Actinopolyspora halophila and Actionopolyspora mortivallis.

In this study, 12 Gram positive and 17 Gram negative bacteria were susceptible to the antibiotic metabolites produced by the test actinomycetes with those from Actinopolyspora (NB 069 and TR 008) being least active in comparison with those from Streptomyces (TR 007) and Actinoplane (NB 034). The antibiotic metabolites from Actinopolyspora [NB 069] which was isolated from the marine environment was active against Gramnegative bacteria while that of Actinopolyspora (TR 008) isolated from freshwater was active against both Gram positive and Gram negative bacteria and in contradiction with the observation of Kokare et al. (2004) who reported that Actinopolyspora species usually show good activity against Gram-positive bacteria, but usually lacking activity against Gram-negative bacteria, and this report was further corroborated by other workers (Pandey et al., 2004; Oskay et al., 2004). The reason for the difference in sensitivity between Gram positive and Gram negative bacteria could be attributed to the morphological 
Table 3. Rate of kill for extract Streptomyces [TR 007] against selected susceptible test bacteria at different MICs.

\begin{tabular}{|c|c|c|c|c|c|c|c|}
\hline \multirow{2}{*}{ Isolates } & \multirow[b]{2}{*}{ MIC (mg/ml) } & \multicolumn{2}{|c|}{$\log _{10}$ kill (MIC) } & \multicolumn{2}{|c|}{$\log _{10}$ kill $(2 \times M I C)$} & \multicolumn{2}{|c|}{$\log _{10}$ kill $(4 \times M I C)$} \\
\hline & & $6 \mathrm{~h}$ & $12 \mathrm{~h}$ & $6 \mathrm{~h}$ & $12 \mathrm{~h}$ & $6 \mathrm{~h}$ & $12 \mathrm{~h}$ \\
\hline Staphylococcus aureus $\mathrm{OKOH} 2 \mathrm{~A}^{\mathrm{TM}}$ & 1.25 & 0.22 & 0.44 & 0.32 & 0.56 & 0.38 & 0.73 \\
\hline Klebsiella pneumoniae ATCC 4352@ & 0.156 & 0.04 & -2.11 & 0.04 & -2.02 & 0.70 & -1.26 \\
\hline Staphylococcus sciuri $\mathrm{OKOH} 2 \mathrm{~B}^{\mathrm{TM}}$ & 0.156 & 0.81 & 0.51 & 0.82 & 0.65 & 0.88 & 0.85 \\
\hline Escherichia coli ATCC 25922@ & 0.315 & -1.18 & ND & -0.95 & -2.20 & -0.93 & -1.20 \\
\hline
\end{tabular}

MIC represents minimum inhibitory concentration; ND- not determined; ${ }^{\mathrm{TM}}$ Clinical isolates; ${ }^{@}$ Reference strains

Table 4. Rate of kill for extract Actinopolyspora [TR 008] against selected susceptible test bacteria at different MICs.

\begin{tabular}{|c|c|c|c|c|c|c|c|}
\hline \multirow{2}{*}{ Isolates } & \multirow[b]{2}{*}{ MIC (mg/ml) } & \multicolumn{2}{|c|}{$\log _{10}$ kill (MIC) } & \multicolumn{2}{|c|}{$\log _{10}$ kill $(2 \times M I C)$} & \multicolumn{2}{|c|}{$\log _{10}$ kill $(4 \times M I C)$} \\
\hline & & $6 \mathrm{~h}$ & $12 \mathrm{~h}$ & $6 \mathrm{~h}$ & $12 \mathrm{~h}$ & $6 \mathrm{~h}$ & $12 \mathrm{~h}$ \\
\hline Micrococcus luteus@ & 0.039 & 0.89 & -1.06 & 1.04 & -0.95 & 1.11 & -0.64 \\
\hline Klebsiella pneumoniae@ & 0.039 & -1.14 & ND & -1.07 & -2.18 & -1.02 & -2.28 \\
\hline
\end{tabular}

MIC represents minimum inhibitory concentration; ${ }^{\circledR}$ Environmental strains; ND- not determined.

differences between these microorganisms, Gram negative bacteria having an outer polysaccharide membrane carrying the structural lipopolysaccharide components which makes the cell wall impermeable to lipophilic solutes, unlike the Gram positive bacteria that has only an outer peptidoglycan layer which is not an effective permeability barrier.

The antibacterial activities of the antimicrobial compounds from the test actinomycetes at such low concentrations as $0.039 \mathrm{mg} / \mathrm{ml}$ supports the popular notion that actinomycetes can be sources of potent antibacterial agents that can be of value in the treatment of infections especially those caused by clinicallyresistant bacteria, such as Staphylococcus aureus and Klebsiella pneumoniae (Oskay et al., 2004). Also, the susceptibility of Klebsiella pneumoniae to extract from Actinopolyspora [TR 008] at such low concentration of $0.039 \mathrm{mg} / \mathrm{ml}$ Table 2 is an important finding as this pathogen is known to rank second (after Escherichia coli) with regards to antibiotics resistance in urinary tract infections (Gupta et al., 2001).

Bactericidal activity was defined as a reduction of $99.9 \%\left(\geq 3 \log _{10}\right)$ of the total count of $\mathrm{CFU} / \mathrm{ml}$ to the original inoculum while bacteriostatic activity was defined as maintenance of or a reduction of less than $99.9 \%(<3$ $\log _{10}$ ) of the total count of $\mathrm{cfu} / \mathrm{ml}$ in the original inoculum (CLSI, 2005). The present study demonstrated a clear concentration-dependent rate of kill for all the test bacteria exposed to the culture extracts of Streptomyces (TR 007) and Actinopolyspora (TR 008). Some of the test organisms were susceptible during screening but resistant to killing during the time kill studies for example, extract Streptomyces (TR 007) against Escherichia coli(ATCC 25922) and extracts Actinopolyspora (TR 008) against Klebsiella pneumonia. Similar observation has been reported for fumaradimycine an antibiotic isolated from Streptomyces was found to be active only in agar medium but not in broth (Hacene et al., 2000). The results suggest the dependence of the production of antimicrobial compound(s) on medium constituents as previously corroborated by the report of Holmalahti et al., (1998) who showed that the nature of medium composition strongly affected antimicrobial compounds production in different organisms. Peterson et al. (2007) reported that a strain of Klebsiella pneumoniae once had growth that was higher than the initial inoculums, the mechanisms behind this observation have not been determined. Nevertheless, this may not be unrelated to the characteristics of the lipopolysaccharides (LPS) found in Gram negative bacteria which contributes to their resistances to antibiotics. The LPS blocks certain antibiotics such as penicillin, dyes, and detergents, protecting the sensitive inner membrane and cell wall (Parungao et al., 2007).

The re-growth pattern observed at $12 \mathrm{~h}$ at all levels of the MIC concentration for Klebsiella pneumoniae Table 3 and Micrococcus luteus Table 4 suggests a temporary inhibition of growth by the crude extract which was then lost after $6 \mathrm{~h}$ probably due to adaptation of the test bacteria to the extract (Tam et al., 2005). Extract TR007 had a reduction in bacterial count ranging from $0.22 \log _{10}$ $0.88 \log _{10} \mathrm{cfu} / \mathrm{ml}$ which demonstrated a pattern of bacteriostatic activity against the two out of the four test organisms Staphylococcus aureus $\mathrm{OKOH} 2 \mathrm{~A}$ and Staphylococcus sciuri OKOH2B. The reduction in viable bacterial counts was typically less than $3 \log _{10} \mathrm{cfu} / \mathrm{ml}$ indicative of bacteriostatic effect. No bactericidal activity was noted with any of the extracts studied. 


\section{Conclusion}

This study shows that the test actinomycetes have potentials as sources of new antibacterial compounds or lead compounds in new drug discovery. In particular, the antibacterial activities of the crude ethyl acetate extract of some of the actinomycetes products even at very low concentrations is particularly encouraging and opens up a vista for further research opportunities in our group towards elucidating and characterizing the active compound(s) in the antibiotic metabolites.

\section{ACKNOWLEDGMENT}

We are grateful to the National Research Foundation (NRF) of South Africa for the grant which supported this study.

\section{REFERENCES}

Berdy J (1974). Recent developments of antibiotic research and classification of antibiotics according to chemical structure. In: Perlman D (ed) Advances in applied microbiology. Academic, New York. pp.308- 406.

Bull AT, Ward AC, Goodfellow M (2000). Search and discovery strategies for biotechnology: the paradigm shift. Microbiol. Mol. Biol. Rev., 64: 573- 606.

CLSI (Clinical and Laboratory Standards Institute) (2005). Performance standards for antimicrobial susceptibility testing. CLSI approved standard M100-S15. Wayne, PA.

Coronelli C, Tamoni G, Lancini GC (1976). Gardimycin, a new antbiotic from actinoplane II. Isolation and preliminary characterization. Research Laboratories, Gruppo Lepetit, S.p.A. Via Durando., 38: 20158.

EUCAST (2000). Terminology relating to methods for the determination of susceptibility Definitive Document E. Def 1.2 of bacteria to antimicrobial agents. Clin. Microbiol. Infect., 6: 9.

EUCAST (2003). European Committee for Antimicrobial Susceptibility Testing Determination of minimum inhibitory concentrations (MICs) of antibacterial agents by broth dilution. Clin. Microbiol. Infect., 9: 1 - 7

Gupta K, Sahm DF, Mayfield D, Stamm WE (2001). Antimicrobial resistance among uropathogens that cause community acquired urinary tract infections in women: A nation wide analysis. Clin. Infect. Dis., 33: 89-94.

Hacene H, Daoudi H, Bhatnagar T, Baratti JC, Lefebvre G (2000). A new aminoglycosidase anti Pseudomonas antibiotic produced by a new strain of Spirillosora. Microbiol., 102: 69.

Holmalahti J, Raatikainer O, Wright A, Laatsch $\mathrm{H}$, Spohr A, Lyngberg OKJ (1998). Production of dihydroabikoviromycin by Streptomyces anualatus, production parameters and chemical characterization of genotoxicity. J. Appl. Microbiol., 85: 61-68.

Jensen PR, Fenical W (2000). Marine Microorganisms and Drug Discovery: Current Status and Future Potential. Fusetani N (ed: Drugs from the Sea. Basel, Karger. pp.6-29.

Kampfer P (2006). The Family Streptomycetaceae, Part I: Taxonomy. The prokaryotes: a handbook on the biology of bacteria (Dworkin, M et al, eds.). Berlin: Springer. pp. 538-604.

Karimaki K, Parkkinen T, Santa H, Pastinen O, Leisola M, Rouvinen J, Turunen O (2004). Engineering the substrate specificity of xylose isomerase. Protein Eng. Des. Sel., 17: 861- 869.

Kieser T, Bibb MJ, Buttner MJ, Chater KF, Hopwood DA (2000). Practical Streptomyces Genetics ( $2^{\text {nd }}$ ed.). Norwich, England: John Innes Foundation.

Kokare CR, Mahadik KR, Kadam SS, Chopade BA (2004). Isolation, characterization and antimicrobial activity of marine halophilic
Actinopolyspora species AH1 from the West coast of India. Curr. Sci., 86: 593-597.

Madigan M, Martinko J (eds.) (2005). Brock Biology of Microorganisms (11th ed. ed.).Prentice Hall.

Mincer TJ, Jensen PR, Kauffman CA, Fenical W (2002). Widespread and persistent populations of a major new marine actinomycete taxon in ocean sediments. Appl. Environ. Microbiol., 68: 5005- 5011.

Ogunmwonyi INH (2008). Actinomycetes diversity of Tyume River and Nahoon beach. Honours dissertation submitted to Department of Biochemistry and Microbiology, University of Fort Hare, Alice South Africa.

Okami Y, Hotta K (1988). Search and discovery of new antibiotics In M. Goodfellow, S. T. Williams, and M. Mordarski (ed.), Actinomycetes in biotechnology. Academic Press, Inc., New York, pp. 33-67.

Okoli S, Iroegbu CU (2005). In vitro antibacterial activity of Synclisa scabrida whole root extract. Afr. J. Biotechnol., 4: 946-952.

Omura S (2001). Genome sequence of an industrial microorganism Streptomyces avermitilis: Deducing the ability of producing secondary metabolites. Proc. Natl. Acad. Sci., USA. 98: 1221512220.

Oskay M, Tamer AU, Azeri C (2004). Antibacterial activity of some actinomycetes isolated from farming soils of Turkey. Afr. J. Biotechnol., 3: 441-446.

Pandey B, Ghimire P, Agrawal VP (2004). Studies on the antibacterial activity of actinomycetes isolated from the Khumbu region of Mt. Everest. A paper presented in the International Conference on the Great Himalayas: Climate, Health, Ecology, Management and Conservation, Kathmandu. January 12-15. Organized by Kathmandu University and the Aquatic Ecosystem Health and Management Society, Canada.

Parungao MM, Maceda EBG, Villano MAF (2007). Screening of antibiotic-producing Actinomycetes from marine, brackish and terrestrial sediments of Samal Island, Philippines. J. Res. Sci. Comput. Eng., 4: 29-38.

Petersen PJ, Jones CH, Bradford PA (2007). In vitro antibacterial activities of tigecycline and comparative agents by time-kill kinetic studies in fresh Mueller-Hinton broth. Diag. Microbiol. Infect. Dis., 59: 347- 349

Sibanda T, Okoh Al (2008). In vitro antibacterial regimes of crude aqueous and acetone extracts of Garcinia kola seeds. J. Biol. Sci., 8 . 149-158.

Sibanda T, Mabinya LV, Mazomba N, Akinpelu DA, Bernard K, Olaniran $\mathrm{AO}$ and Okoh Al (2010). Antibiotic producing potentials of three freshwater actinomycetes isolated from the Eastern Cape Province of South Africa. Int. J. Molecular. Sci., 11: 2612-2623.

Tam VH, Schilling AN, Nikolaou M (2005). Modelling time-kill studies to discern the pharmacodynamics of meropenem. J. Antimicrob. Chem. 55: 699-706.

Thakur D, Yaday A, Gogoi BK, Bora TC (2007). Isolation and screening of Streptomyces in soil of protected forest areas from the states of Assam and Tripura, India, for antimicrobial metabolites. J. Med. Mycol., 17: 242-249.

Vandamme EJ (1984). Antibiotic search and production: an overview. In: Vandamme EJ (ed) Biotechnology of industrial antibiotics. Marce Dekker, New York. pp.3-32.

Watve MG, Tickoo R, Jog MM, Bhole BD (2001). How many antibiotics are produced by the genus Streptomyces, Arch. Microbiol., 176: 386 390.

Wynands K, van Pée H (2004). A novel halogenase gene from the pentachloropseudilinproducer Actinoplanes sp. ATCC 33002 and detection of in vitro halogenase activity. FEMS Microbiol. Lett., 237 363-367.

Xiao-Yang Z, Ling-Ling Y, Jin-Yuan W, Shu-Kun T, Wen-Jun L (2000). Extremophiles Publisher Springer Japan Category Method, pp.543548

Zhang YX, Perry K, Vinci VA, Powell K, Stemmer WP, del Cardayre SB (2002). Genome shuffling leads to rapid phenotypic improvement in bacteria. Nature, 415: 644- 646. 